\title{
THE EFFECT OF IMPROVEMENT ON WORK FACILITY OF COCO BRISTLE PROCESS TO OCCUPATIONAL HEALTH AND SAFETY
}

\author{
Listiani Nurul Huda ${ }^{1)}$, Indra Nasution ${ }^{2)}$ \\ ${ }^{1)}$ Departement of Industrial Engineering, University of Sumatera Utara, Medan, Indonesia \\ Email: lnurulh@gmail.com \\ ${ }^{2)}$ Departement of Industrial Engineering, University of Sumatera Utara, Medan, Indonesia \\ Email: Nasution.indra@usu.ac.id
}

\begin{abstract}
One of improvements on health and safety can be carried out by the improvement on work facilities used by workers during the production process. This research was conducted in one of manufacture of coco bristel which the machines are not designed ergonomically. Work posture of the worker are in standing position during the processing of coco bristle and the body position is bending that can causes fatigue at the back and spine. On the other hand, the coco bristle machine is not ergonomically designed to maintain security as workers shrink the outer shell of coir. Pulling velocity of coconut husk by spinning pliers may result in hand drawn towards the nail. Therefore, this research is needed to carried out in order to re-design the coco bristel machine so that workers can work more healthily and safely. The method used in this research is work posture asessment by Rapid Entire Body Assessment (REBA) and anthropometric concept to re-design coco bristle machine. The results show that the actual machine design gives a REBA score of 6 indicating that improvement of work posture is in need of improvement. The improvement is carried out by redesign of the machine through consideration to the most dominant body dimension influenced the work of making coco bristel. These dimensions are the height of the elbows at standing position, hand reach, and hand grip. This improved machine design resulted in a smaller REBA score by two points than before which means that the spinal position tends to be in a more healthier position than before. As for the safety of using the machine, hand protection is added based on the dimension of hand grip. The results of this study indicate that there is a strong relationship between the machine design and size dimensions of the worker's body with the level of security and health in the work.
\end{abstract}

Keywords: Work facility, REBA, working posture, machine redesign, coco bristle

\section{INTRODUCTION}

Indonesia is able to produce 18.3 million tons of coconut per year and is the largest producer of coconuts in the world. Exports of Indonesia's coconut derivative products also ranked first in the world in terms of quantity, but only ranked second in terms of profit. This is because the selling value of Indonesian coconut derivative products is still lower compared to rival countries such as the Philippines and Sri Lanka [3]. In addition to the different types of coconuts produced in each country, other causes are due to the fact that coconut derived production in Indonesia is still experiencing a lack of research development for both product development and the development of production system and other support systems. It can be seen from the data that $72.16 \%$ of Indonesia's copra is exported to the Philippines, while the Philippines sells copra that has been processed into coconut oil and copra meal for export [6]. This is why the export earnings of Philippine coconut derived products are higher than in Indonesia. While Indonesia exports most of its products in the form of copra, the Philippines sell them in the form of oil and copra meal which certainly has a higher selling power.

The same is true of coco
bristle products or better known
by name bristle fiber. Although Indonesia is
the largest coconut producing country in the
world, its coconut fiber processing products


are still far behind compared to India and Sri Lanka. Based on the average data from international trade, a coconut can produce 0.15 kilograms of coco fiber and 0.39 kilogram coco peat. Based on data from the association of Indonesian coconut husk industry (AISKI), the selling price of coco fiber and coco peat in the domestic market consecutively ranges between $\mathrm{Rp} 2,000-\mathrm{Rp}$ 2,500 per kilo and $\mathrm{Rp} \mathrm{1,000} \mathrm{-} \mathrm{Rp} \mathrm{1,500} \mathrm{per}$ kilogram. Coconut production in Indonesia reaches fifteen billion pounds per year and which can be processed only reach to 480 million grains or 3.2 percent, it is estimated that Indonesia loses Rp 13 Trillion per year from unprocessed coconut husk [4]. Therefore it is necessary to research the development of coconut processing business, one of which can be done with the design of work systems.

The design of work system aims to produce a comfortable working system, safe, and healthy for workers and produce output in accordance with the desired. The design of the work system has three variables, namely the use of the human body, preparation and workplace conditions, as well as the design of tools and equipments. The improvement of the work system design should pay attention to these three variables well [1].

This study focuses on the improvement of two aspects in the design of the work system, which are the design of equipment and the use of the human body to increase the production of one of the coconut derivatives, namely coco bristle. One coconut can produce $35 \%$ coconut husk. From this coconut husk can be processed into coco fiber products i.e coconut husk that has been decomposed into fibers. This coco fiber products can be processed into coco bristle and coco peat. Coco fiber can be processed into tiles, coco charcoal, coir carpet which called Mourzouks, coir belts, and others. While coco bristle can be used to make products such as sofa, motor seat, brush, doormat, spring bed and others. While coco peat is generally used as a medium for planting and organic fertilizer [8].
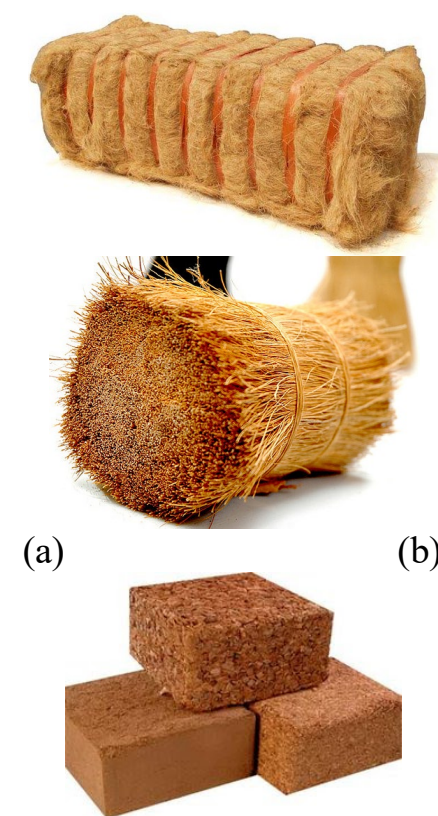

(c)

Figure 1. (a) Coco Fiber (b) Coco Bristle (c) Coco Peat

At the research location, coco bristle processing is done by using machine called coco bristle machine. This machine has two parts, where the first part serves to destroy the outer coconut skin. The production process is the operator pinning the tip of the coir then put it into the machine so that the coconut outer shell is destroyed and leaves the long fibers called coco bristle. This step is done repeatedly for both sides. The second part serves to destroy the tip of the coir that is still there to get a clean coco bristle from the outer skin. The steps taken are the operator holding the finished coco bristle part and pinning the remaining heads, and done repeatedly. Such parts may be dangerous to the operator if the operator's hand is drawn into it. The operator does not use any safety device to protect his hand from the machine. This shows that the design of the machine still does not pay attention to the safety of the workers .

Research on coconut coir machine design has been done before in [2] and [5], but there is no further research especially on the design of coco bristle machine. Therefore, the improvement of coco bristle engine 
Listiani. et.al. The Effect of Improvement on Work Facility of Coco Bristle Process to Occupational Health And Safety

design is expected to increase the amount of production so that the company can meet the demand while increasing the comfort and security of the operator.

In this research will be designing coco bristle machine with anthropometry approach. The machine will be designed to fit the worker's body dimensions and will be designed to get a safer and more convenient way of working .

\section{MEthodology}

This research was conducted on a coconut processing SME but the research object focused on coco fiber making. The research procedures conducted in this research are:

\section{1) Preliminary Research}

This stage is used to diagnose the problems found in coco bristle making work stations. At this stage, the data on the initial machine specifications are also collected as the design basis.

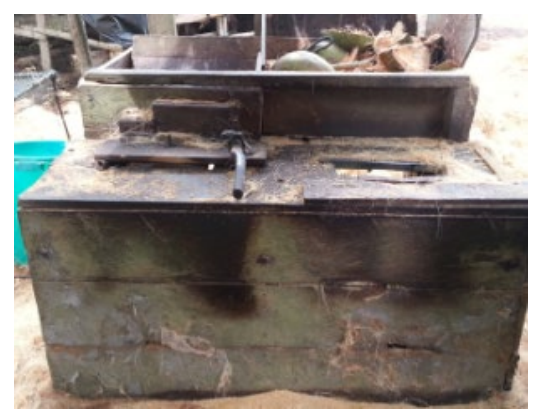

Figure 2. Condition of Coco Bristle Initial Machine

\section{2) Assessment of Operator Posture}

Field studies are conducted to obtain data on the operator's body posture while working. This data is collected in the REBA (Rapid Entire Body Assessment) method of valuation table. REBA is used to evaluate the work posture and muscle of operators where repetitive work is associated with abnormalities throughout the body. The REBA assessment covers the whole body and legs [7]. The REBA assessment was performed using REBA worksheets conducted by researchers.

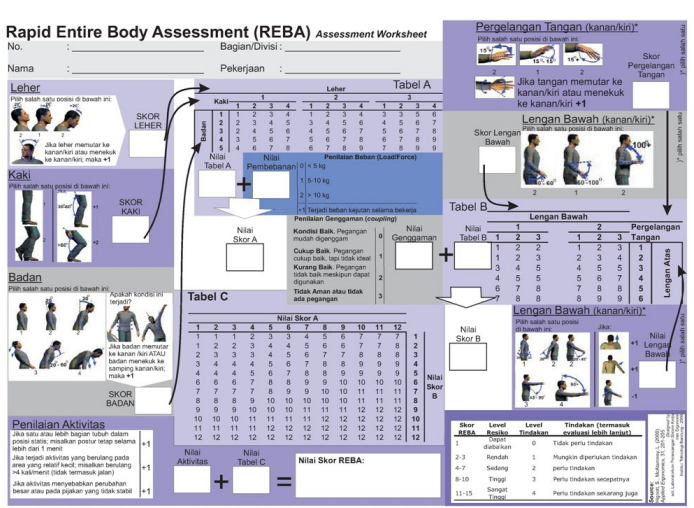

Figure 3. REBA Worksheet

Each of the worker's (top and bottom) body parts is scored by its appropriateness to the points on the worksheet. The total value of all points is the desired end value. This final value is an indication of the risk of the work posture examined. The REBA rating category is divided into five categories as shown in Table 1.

Tabel 1. REBA Rating Categories

\begin{tabular}{|c|c|c|c|}
\hline $\begin{array}{l}\text { REBA } \\
\text { Score }\end{array}$ & $\begin{array}{c}\text { Risk } \\
\text { Level }\end{array}$ & $\begin{array}{l}\text { Action } \\
\text { Level }\end{array}$ & Action \\
\hline 1 & Negligible & 0 & $\begin{array}{l}\text { No action } \\
\text { required }\end{array}$ \\
\hline $2-3$ & Low & 1 & $\begin{array}{l}\text { May need } \\
\text { action }\end{array}$ \\
\hline $4-7$ & Medium & 2 & $\begin{array}{l}\text { Action required } \\
\text { Needs }\end{array}$ \\
\hline $8-10$ & High & 3 & $\begin{array}{l}\text { immediate } \\
\text { action }\end{array}$ \\
\hline $11-15$ & Very high & 4 & $\begin{array}{l}\text { Needs action } \\
\text { right now }\end{array}$ \\
\hline
\end{tabular}

3) Anthropometry Data Processing

Dimensions of operator's body are measured and processed statistically (mean, standard deviation, and uniformity data) to obtain data on required to find the percentile dimensions for designing tools. Instruments used for the measurement of body dimensions include: 
a) Goniometer

This instrument is used to measure the angle of the operator body. Example of goniometer can be seen from Figure 4.

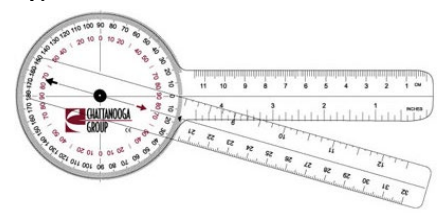

Figure 4. Goniometer Tool

\section{b) Length Gauge}

This instrument is used to measure operator body dimensions. The sample of length gauge used can be seen in Figure 5.

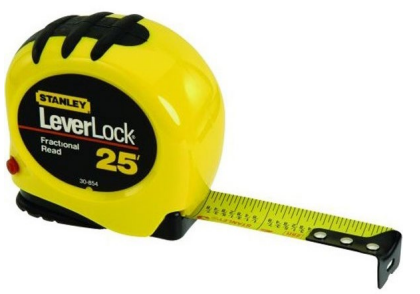

Figure 5. Length Gauge

The anthropometric data used are:

a) Elbow at Standing Position

Elbow height at standing position is used to determine the height of the work surface. This is in accordance with the principle of the workplace, where the height of the working surface should be determined from a convenient work posture for the operator. Generally, this means that the upper arm is hanged naturally and the elbow is bent at $90^{\circ}$ [3]. This may reduce the score on the operator's work posture assessment.

b) Hand Reach

Hand reach is incorporated into the design of the new engine so that the operator is more comfortable when picking or placing the coir into the container.

c) Handheld Diameter

Handheld diameter used to determine the grip diameter used when the operator clamps coconut coir. The corresponding diameter will allow the operator to grasp the handle.

\section{4) Machine Redesign}

The new coco bristle machine is designed with consideration of anthropometry and safety. The design of the tool will be done in the form of 3D commuter graphics using AutoCAD.

\section{5) Machine Testing}

Machines that have been designed and manufactured will be trials and then REBA assessments will be conducted again made to see the effects of new machines on worker posture.

\section{RESULT AND DISCUSSION}

\subsection{Working Posture Rating}

The posture examined is the operator working posture when standing using coco bristle machine. The work posture is shown in Figure 6.

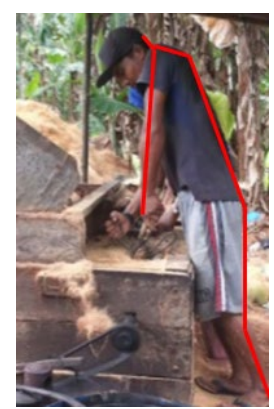

Figure 6. Operator's Working Posture of

Workers at Coco Bristle Machine

The work posture is assessed by the REBA method of six operators working on coco bristle machine. The results of the REBA assessment recapitulation are shown in Table 2 . 
Listiani. et.al. The Effect of Improvement on Work Facility of Coco Bristle Process to Occupational Health And Safety

\begin{tabular}{ccc}
\multicolumn{3}{c}{ Table 2. REBA Assessment Recapitulation } \\
\hline Operator & Score & Information \\
\hline 1 & 6 & Action required \\
2 & 6 & Action required \\
3 & 5 & Action required \\
4 & 5 & Action required \\
5 & 6 & Action required \\
6 & 6 & Action required \\
\hline
\end{tabular}

In accordance with the REBA scoring criteria, the mean six scores obtained for each operator indicate there is a need for corrective action. An improvement made is to do a new machine design because the current work posture is problematic because of the shape of the machine that requires as such.

\subsection{The New Coco Bristle Machine Design}

The design of the new machine is done by considering the anthropometry dimension of the worker and the user safety. Improvement made is also a response to the weaknesses in the old machine as described below:

\section{1) Aspects of Anthropometric Dimension of New Coco Bristle Machine}

The initial coco bristle machine dimension can be improved by designing a machine with dimensions that match the operator's body dimensions. Therefore, it is necessary to calculate the anthropometric data of the operators. There are three body dimensions used in the design of the new engine coco bristle. The body dimensions used can be seen in Table 3.

Table 3. Body Dimensions Used

\begin{tabular}{ccc}
\hline No & Body Dimensions & Percentiles \\
\hline 1 & Elbow at Standing & P50 \\
& Position (TSB) & \\
2 & Hand Range (JT) & P50 \\
3 & Handheld Diameter (DG) & P50 \\
\hline
\end{tabular}

There are six measurement results according to the number of operators. The results of these measurements can be seen in Table 4.
Table 4. Operator Body Dimensions

\begin{tabular}{ccccc}
\hline & & \multicolumn{2}{c}{ Body Dimension (cm) } \\
\cline { 3 - 5 } $\mathbf{N}$ & $\begin{array}{c}\text { Operat } \\
\text { or } \\
\mathbf{~ a t ~}\end{array}$ & $\begin{array}{c}\text { Standi } \\
\text { ng } \\
\text { Positio } \\
\mathbf{n}\end{array}$ & $\begin{array}{c}\text { Han } \\
\text { d } \\
\text { Rang } \\
\text { e }\end{array}$ & $\begin{array}{c}\text { Handhe } \\
\text { dd } \\
\text { Diamete } \\
\mathbf{r}\end{array}$ \\
\hline 1 & $\begin{array}{c}\text { Operato } \\
\text { r 1 }\end{array}$ & 103.0 & 74.0 & 4.4 \\
2 & $\begin{array}{c}\text { Operato } \\
\text { r 2 }\end{array}$ & 102.6 & 73.3 & 3.9 \\
3 & $\begin{array}{c}\text { Operato } \\
\text { r 3 }\end{array}$ & 103.3 & 75.0 & 4.6 \\
4 & $\begin{array}{c}\text { Operato } \\
\text { r 4 }\end{array}$ & 103.1 & 73.9 & 4.5 \\
5 & $\begin{array}{c}\text { Operato } \\
\text { r 5 }\end{array}$ & 103.0 & 74.1 & 4.3 \\
6 & $\begin{array}{c}\text { Operato } \\
\text { r 6 }\end{array}$ & 102.9 & 73.6 & 3.8 \\
\hline
\end{tabular}

The measurements of body dimensions were then analyzed statistically. The mean values, standard deviations, as well as upper and lower control limits are calculated to see if the data obtained are uniform. The result of uniformity test of the data for the calculation result of body dimension is shown in Table 5.

Table 5. Uniformity Test of Body Dimensions Data

\begin{tabular}{cccccc}
\hline $\mathbf{N}$ & $\begin{array}{c}\text { Measurem } \\
\text { ent }\end{array}$ & $\bar{x}$ & $\mathbf{S}$ & $\mathbf{N}$ & $\begin{array}{c}\text { Informat } \\
\text { ion }\end{array}$ \\
\hline \multirow{2}{*}{1} & TSB & 102, & 0,2 & 6 & In \\
& & 98 & 3 & 6 & Control \\
& & 73,9 & 0,5 & & In \\
2 & JT & 8 & 8 & 6 & Control \\
& & & 0,3 & & In \\
3 & DG & 4,25 & 3 & 6 & Control \\
\hline
\end{tabular}

The results of the statistics test show that all data is within the limits, which means the data can be further processed data. The next processing is to calculate the percentile of data. Percentile used for elbow height at standing position is fifty percentile, hand reach is fifty percentile, and handheld is also fifty percentile. 
Listiani. et.al. The Effect of Improvement on Work Facility of Coco Bristle Process to Occupational Health And Safety

1. Calculation of dimension percentile of Elbow at Standing:

$$
\begin{aligned}
& P_{50}=\bar{x}+k s \\
& =102,98+0(0,23) \\
& =102,98 \mathrm{~cm}
\end{aligned}
$$

2. Calculation of dimension percentile of Hands Reach:

$$
\begin{aligned}
& P_{50}=\bar{x}+k s \\
& =73,98+0(0,58) \\
& =73,98 \mathrm{~cm}
\end{aligned}
$$

3. The calculation of percentile dimension of Handheld Diameter:

$$
\begin{aligned}
& P_{50}=\bar{x}+k s \\
& =4,25+0(0,33) \\
& =4,25 \mathrm{~cm}
\end{aligned}
$$

\section{2) Security Aspect of New Coco Bristle Machine}

The safety aspect of the coco bristle machine is required in the design of the new machine, in accordance with the results of the open questionnaire asked to the respondent. New machine security can be realized by adding some detail to the new machine to improve the security of the machine compared to the old machine.

The addition is the addition of a layer of wood on the lid when clamping the tip of the coir. This is done to reduce the risk of work accidents in the form of the operator's hand pull into the wooden scroll when pinning the tip of the coir. The clamping section of the coir tip of the starting machine can be seen in Figure 7.

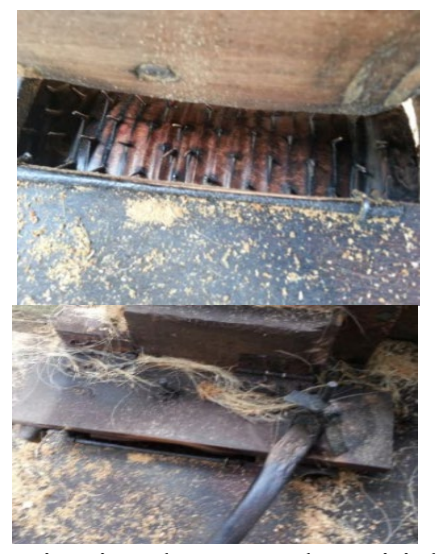

Figure 7. Coir Tip Clamp on the Initial Machine
The addition of wood coating on coco bristle machine design can be seen in Figure 8.

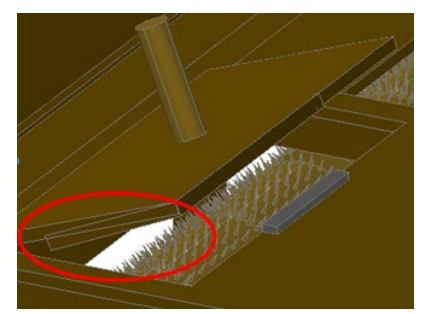

Figure 8. The Addition of Wood Coating on New Coco Bristle Machine

Besides that, the addition is also done on rubber pads at the end of the hole at the tip of the coir clamp. The addition of this rubber pad can be seen in Figure 9.

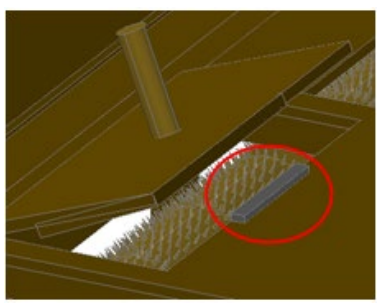

Figure 9. Rubber Pads Addition on the New Coco Bristle Machine

Based on the characteristics, dimensions, and safety aspects wanted, a new Coco Bristle machine was designed. The 3D AutoCAD design and original New Coco Bristle machine product can be seen in Figure 10 through Figure 16.

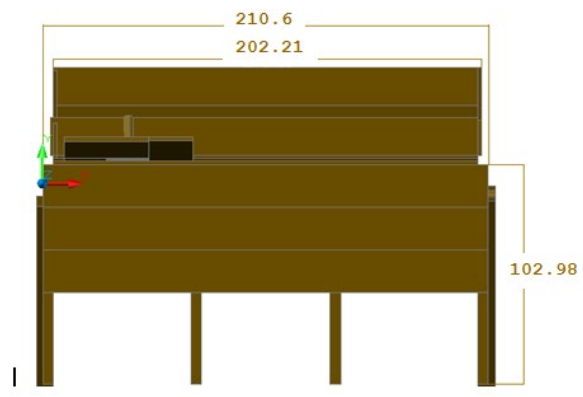

Figure 10. Front View of New Coco Bristle Machine Design 
Listiani. et.al. The Effect of Improvement on Work Facility of Coco Bristle Process to Occupational Health And

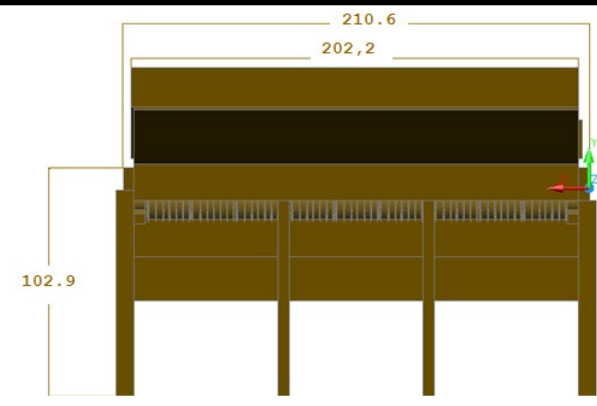

Figure 11. Back View of New Coco Bristle Machine Design

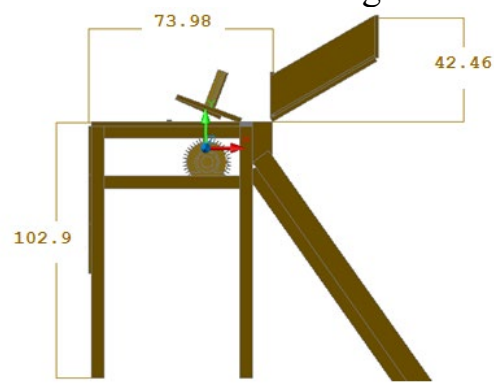

Figure 12. Right View The New Coco Bristle Machine Design

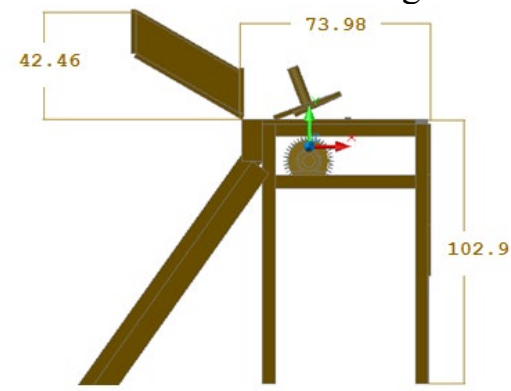

Figure 13. Left View of New Coco Bristle Machine Design

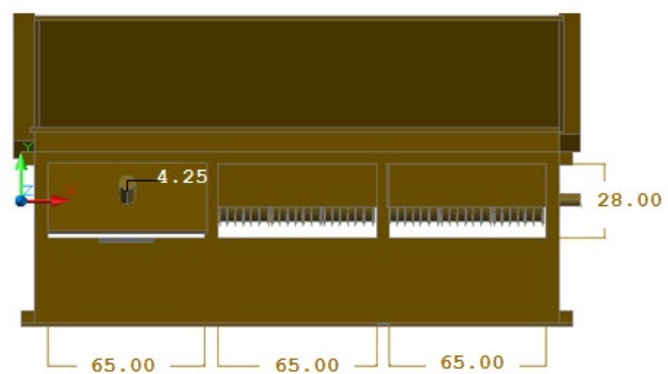

Figure 14. Top View of New Coco Bristle Machine Design

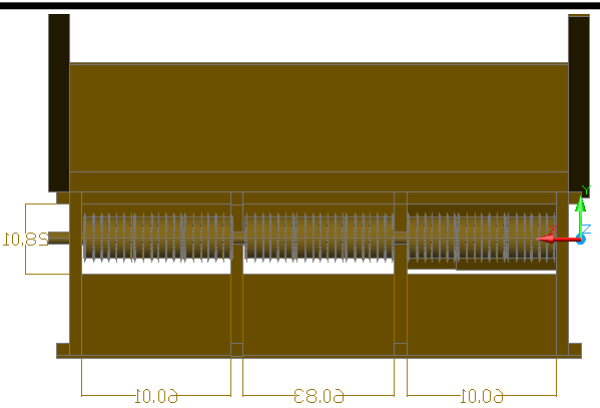

Figure 15. Lower View of New Coco Bristle Machine Design

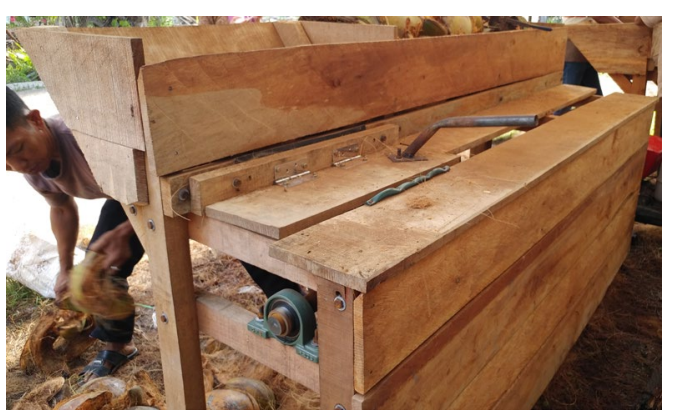

Figure 16. New Coco Bristle Machine Products

\subsection{New Coco Bristle Machine Machine Testing}

Machine testing is performed to assess machine performance. The main purpose of designing this new machine is to create a machine that is more secure and comfortable to use. Therefore, testing should be done to assess whether the desired goal has been achieved.

Testing is done by assessing the worker's posture when using a new machine using REBA. The assessment results show an average score of four, which means the score has dropped two points from the REBA calculation on the initial machine. This indicates that this machine is more secure and comfortable to use in work. The safety level of the new machine is considered safer and easier to use by the workers, especially the handheld security that has been designed in accordance with the dimensions of the hand grip is safer to use than the old machine. 
Listiani. et.al. The Effect of Improvement on Work Facility of Coco Bristle Process to Occupational Health And Safety

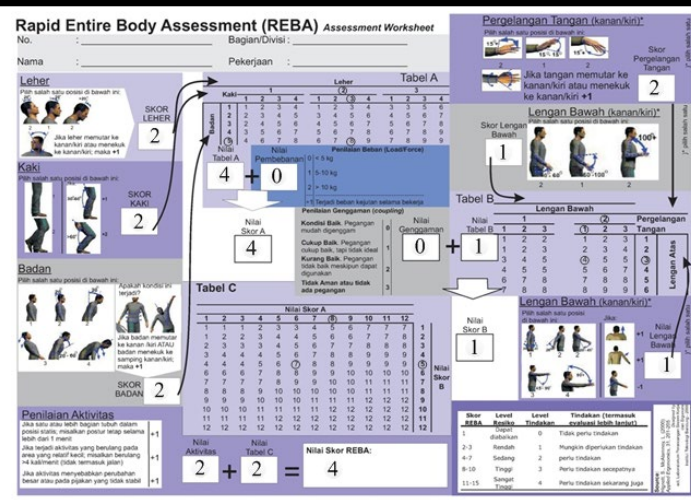

Figure 17. Results of the Calculations of REBA for New Coco Bristle Machine

\section{Conclusion}

The results showed that there is a close relationship between the design and the dimensions of the tool with the level of security and health in work. This can be seen from the decrease in REBA scores up to two points and machine design that has been made is more secure. This finding is not only found in this study. Some other studies such as [9] who designed the hand tool for screen textile printing also found that there was a decrease in pain in the lower back area by $29 \%$ from $75 \%$, pain in the shoulder was also reduced to $33 \%$ from $74 \%$ by using the new tool.

This study used a different approach from previous research [2] which also redesigned coconut coir machine. The study uses a more focused participatory approach to make improvements related to the utilization and use of tools. However, such an approach can be considered for further research given that the design of Coco Bristle machine with ergonomic principles has not been done before this research.

\section{ACKNOWLEDGMENT}

We would like to thank the Rector of University of Sumatera Utara for funding this project through a Program Pengabdian Tahun 2018 scheme. In addition, our sincere thank also goes to the Community Service Institute of the University of Sumatera Utara for the facilities during the completion of this project.

\section{REFERENCES}

[1] B. Niebel, Andris Freivalds,"Methods standards and work designs," New York: McGraw-Hill, 2007.

[2] H. widananto and H. Purnomo, "Rancangan mesin pengupas sabut kelapa berbasis ergonomi parsipatori," presented at National Seminar IENACO, 2013, unpublished.

[3] James Burton, "The world leaders in coconut production," 2013, cited from https://www.worldatlas.com/articles/theworld-leaders-in-coconut-production.html

[4] N. Nara, "Bakar sabut kelapa, Rp 13 triliun menguap," 2012, cited from http://ekonomi.kompas.com/read/2012/11/11 /04331576/Bakar.Sabut.Kelapa.Rp.13.Triliu n.Menguap

[5] F.T. Villa, "Coconut husk mini-chipper machine," IJERGS, Vol 4(1), 2016, pp. 611623.

[6] W.D. Herlinda, "Ekspor kelapa RI kalah dari Filipina," 2014, cited from http://industri.bisnis.com/read/20140421/12/ 220920/ekspor-kelapa-ri-kalah-dari-filipina.

[7] A. Bhandhare, "Postural analisis and quantification of fatigue by using rula and reba techniques," IJMPE, Vol. 1(3), 2013.

[8] M. Kavitha, "Production process of coir and coir products," IMPACT: IJRBM, Vol. 3(3), pp.39-47

[9] M.L. Meena, "An ergonomic approach to design hand tool dor screen textile printing," IJMECH, Vol. 4, No. 2, 2015, pp. 59-67. 